\title{
The effects of corporate social responsibility activity disclosure on corporate profitability: Empirical evidence from Nigerian commercial banks
}

\author{
Ajide, Folorunsho Monsuru ${ }^{1}$, Aderemi, Adetunji Abdulazeez ${ }^{2}$ \\ ${ }^{I}$ Department of Accountancy, Lagos State Polytechnic, Ikorodu, Nigeria. \\ ${ }^{2}$ Department of Econs\& Financial studies, Fountain University, Osogbo, Osun state, Nigeria.
}

\begin{abstract}
The study examined the effects of corporate social responsibility activity(CSR) disclosure on bank profitability in Nigeria. Data were sourced from annual report and accounts of twelve sampled commercial banks in Nigeria for the year 2012 only. Variables such as CSR disclosure scores, banks' size and owners' equity serve as independent variables and banks' profitability proxy by returns on equity(ROE) as dependent variable were incorporated into the model. The data were analyzed using multiple regression analysis of Ordinary Least Square(OLS). The results showed that banks' size and CSR disclosure score have a positive relationship with bank profitability while owners 'equity has negative association with bank profitability. It was therefore concluded that banks should increase their level of CSR disclosure as itexhibits greater concern to improve on good corporate image and as a way of showing a greater commitment to impact and improve people's lives which in return capable of improving banks' patronage and profitability.
\end{abstract}

Keywords: Corporate social responsibility, bank's size, profitability, regression analysis.

\section{Introduction}

Corporate Social Responsibility (CSR) concept is deepening among organisations and societies in Nigeria. It is regarded as the organisation's activity to make sustainable impact in society, and which in turn has the potential to create positive effect on the business organizations that engage in it. Business organizations incur huge expenditures on social responsibility because they regard Corporate Social Responsibility (CSR) as a public relations stunt used by large corporations to look good in front of customers and other stakeholders. For instance, it was reported that, in year 2011, the oil and gas sector spent N9.5 billion on CSR, followed by telecoms with N6.4 billion. The banking industry came in third position with the report that a total of N1.869 billion was spent by eight Nigerian banks in 2012 on various community-related projects under corporate social responsibility to identify with the society in which they operate. The figure is about 70 percent of the total CSR expenditure of N3.4 billion by the banking industry in year 2011 with prediction that the figure would double in the next two years due to increased understanding of the concept of CSR (Obi, 2013). However, the large percentage of the expenditure by the banks fall into donations and philanthropy,it was further reported that Nigerian companies perceive and practice CSR as corporate philanthropy aimed at addressing socio-economic development challenges because CSR is still at an early stage in Nigeria(Obi, 2013).

In view of the huge expenditures incurred annually on CSR, it is generally held that corporate social responsibility (CSR) could increase company profits. But few executives and managers are aware of the research on this important subject. Most executives believe that CSR can improve profits. They understand that CSR can promote respect for their company in the marketplace which can result in higher sales, enhance employee loyalty and attract better personnel to the firm. Also, CSR activities focusing on sustainability issues may lower costs and improve efficiencies as well. An added advantage for public companies is that aggressive CSR activities may help them gain a possible listing in the stock exchange, or other similar listing. This may enhance the company's stock price, making executives' stock and stock options more profitable and shareholders happier (Robins, 2011).

However, there is a crying need for an in-depth study into the quality, extent of corporate social responsibility disclosure and identification of areas for future improvement so that transparency can be ensured, especially in developing countries like Nigeria where CSR studies are limited. However, some studies have proved that there is positive association between profitability of firms and CSR expenditures (see Olayinka \& Temitope 2011; Amole, Adebiyi \& Awolaja, 2012), whilesome studies prove negative relationship (e.g Bessong \& Tapang, 2012). This present study intends to look at the effect of corporate social responsibility activity disclosure contentson profitability of Nigerian banks. The remainder of this paper is sectioned into four: the next section is literature review followed by methodology, discussion of results and, conclusion and recommendation ends the discussion. 


\subsection{Conceptual clarifications}

\section{Literature Review}

Corporate social responsibility has no single commonly accepted definition. The concept is a fuzzy one with unclear boundaries. It generally refers to business practices based on ethical values, with respect for people, communities and the environment (Lambardo, 2009). Longe, Necker, Moore, Petty \&Palich (2006) contend that corporate social responsibility comprises varying degrees of conceiting and trustworthy actions of ethical obligations to customers, employees and the community. Mc Oliver \&Yomere (2009) defined social responsibilities at the long range goals of an organization inevitably focused upon its contributions to the needs of society tangible or intangible, its contribution may be in terms of goods or services or both. Keith Davis (2001) views social responsibility as management's decisions and actions taken for reasons at least partially beyond the organizations direct economic or technical interest. Unugbro (2004) defined social responsibility as the obligation of corporate decision-makers to take actions, which protect and improve the welfare of the society which the organization does business. That is to say in addition to their economic and legal obligations, they also owe the society some responsibilities.

Gray, Owen \&Adams (1996.) defined corporate social responsibility disclosure (enhance forth CSRD) as the process of communicating the social and environmental effects of organization economic actions to particular interest groups within the society and to society at larger.Woodward, Edwards \&Birkin (1996) state that CSRD enhances corporate reputation through gaining trust and support by various stakeholders. CSRD assists to evaluate the congruence between the social value implied by corporate activities and social norms (Dowhings\&Pferrer 1975). In addition, social responsibility of firms is necessary for the following reasons: it helps firms to extend aid to societies need; it helps firms to use business resources to promote the interests of all stakeholders affected by a company's operations; social responsibility helps the firm to respond to changing public needs and expectations; it helps the firm or business to recognize its moral obligations; and social responsibility facilitates a firm's correction of some problems caused by the business, for example, pollution of the environment (Ikan, 2004).

\subsection{Theoretical perspectives}

Among others, the most used and quoted theories of corporate social responsibilities (CSR) is Carroll's theory (1991). This model indicates that CSR constitutes major four kinds of social responsibilities, thus; economic, legal, ethical and philanthropic. Carroll considers CSR to be framed in such a way that the entire range of business responsibilities is embraced. The economic component is about the responsibility to profit and this responsibility serves as the base for other components. With regard to the legal aspect, society expects organisations to comply with the laws and regulations.Ethical responsibilities are about how society expects organisations to embrace values and norms even if the values and norms might constitute a higher standard of performance than required by law. Philanthropic responsibilities are those actions that society expect for a company to be a good corporate citizen.

The neoclassical economists advance that the firms should devote their energies to supplying goods and services to their customers, they should minimize costs and maximise profits; and all this should, of course, take place within the laws and rules/regulations of the environments (see Carroll, 1979; Jamali, 2006; Jamali \& Mirshak, 2007; Quazi\& O'Brien, 2000). In addition, some advocates of this viewpoint go as far as to argue that CSR is not only a deflection from the main business of wealth-creation, thus serving to blunt competition, but is also an economic (cost) imposition on the firm (see Friedman, 1999).

In the first instance, Friedman (1970) asserts that engaging in CSR is symptomatic of an agency problem or a conflict between the interests of managers and shareholders. He argues that managers use CSR as a means to further their own social, political, or career agendas, at the expense of shareholders. According to this view, resources devoted to CSR would be more wisely spent, from a social perspective, on increasing firm efficiency. This theory has been tested empirically by Wright \& Ferris (1997), who found that stock prices reacted negatively to announcements of divestment of assets in South Africa, which they interpreted as being consistent with agency theory. The agency theory perspective has been challenged by other researchers, such as Preston (1978) and Carroll (1979), who outline a corporate social performance (CSP) framework. As exposited by Carroll (1979), this model includes the philosophy of social responsiveness, the social issues involved, and the social responsibility categories (one of which is economic responsibility).

Votaw(1972) stated that some theories combine different approaches and use the same terminology with different meanings. To some it conveys the idea of legal responsibility or liability; to others, it means socially responsible behavior in the ethical sense; to still others, the meaning transmitted is that of 'responsible for' in a causal mode; many simply equate it with a charitable contribution; some take it to mean socially conscious; many of those who embrace it most fervently see it as a mere synonym for legitimacy in the context of belonging or being proper or valid; a few see a sort of fiduciary duty imposing higher standards of behavior on businessmen than on citizens at large. However, Carroll (1994), one of the most prestigious scholars in this 
discipline, characterized the situation as a diverse field with loose boundaries, multiple memberships, and differing training/perspectives; broadly rather than focused, multidisciplinary; wide breadth; brings in a wider range of literature; and interdisciplinary'.

Garriga\&Mele'(2004) gave some classifications of CSR, it was assumed that the most relevant CSR theories and related approaches are focused on one of the following aspects of social reality: economics, politics, social integration and ethics. The inspiration for this is rooted in four aspects that, according to Parsons (1961), can be observed in any social system: adaptation to the environment (related to resources and economics), goal attainment (related to politics), social integration and pattern maintenance or latency (related to culture and values). This hypothesis permits to classify these theories in four groups:

1. Instrumental theories: it is assumed that the corporation is an instrument for wealth creation and that this is its sole social responsibility. Only the economic aspect of the interactions between business and society is considered. So any supposed social activity is accepted if, and only if, it is consistent with wealth creation.

2. Political theories: In these theories, the social power of corporation is emphasized, specifically in its relationship with society and its responsibility in the political arena associated with this power. This leads the corporation to accept social duties and rights or participate in certain social cooperation.

3. Integrative theories: this third group includes theories which consider that business ought to integrate social demands. They usually argue that business depends on society for its continuity and growth and even for the existence of business itself.

4. Ethical theories: this relates to the group of theories which understand that the relationship between business and society is embedded with ethical values. This leads to a vision of CSR from an ethical perspective and as a consequence, firms ought to accept social responsibilities as an ethical obligation above any other consideration ( seeGarriga\& Mele',2004).

On the other hands, Secchi (2007) gave a group of theories based on corporate firms' criterion and society. The theories are as follows: the utilitarian theory, the managerial theory, and the relational theory. This can be shown the table 1, below:

Table 1: Utilitarian, managerial and relational theories of CSR

\begin{tabular}{|c|c|c|}
\hline Utility theory & Managerial theory & Relational theory \\
\hline $\begin{array}{l}\text { The theory based on social cost and } \\
\text { functionalism. The utilitarian theory } \\
\text { suggests that the corporation needs to } \\
\text { recognize social duties and } \\
\text { rights to participate in social co-operation. } \\
\text { Within it, the functionalist theory, } \\
\text { specifically advocates that the corporation is } \\
\text { seen as a part of the economic system, } \\
\text { which one of the goals is profit making. The } \\
\text { firm is viewed as an investment, and } \\
\text { investment should be profitable to the } \\
\text { investors and stakeholders. }\end{array}$ & $\begin{array}{l}\text { The theory stressed the logic of managerial } \\
\text { theory that emphasizes corporate } \\
\text { management in which corporate social } \\
\text { responsibilities are approached by the } \\
\text { corporation internally. } \\
\text { This makes the difference between } \\
\text { utilitarian and managerial perspective of } \\
\text { corporate social responsibility. This } \\
\text { suggests that everything external to the } \\
\text { corporation is taken into account for } \\
\text { organizational decision making. }\end{array}$ & $\begin{array}{l}\text { Relational theory has a root from the } \\
\text { complex firm-environment } \\
\text { relationships. } \\
\text { As the term implies, it is the } \\
\text { interrelations between the two are } \\
\text { the focus of the analysis of corporate } \\
\text { social responsibility. It is values- } \\
\text { based as well as interdependent } \\
\text { between the corporation and society. }\end{array}$ \\
\hline
\end{tabular}

Source: Secchi (2007) \&Babalola (2012)

It can be, therefore, concluded that the three groups of CSR theories are as follows: Utilitarian is simplified in its views by the individuals and mechanical from the corporation perspective, managerial is very organizational oriented and measurable; and relational is values-based as well as interdependent between the corporation and society. This could be further strengthened by another not-so-distant conceptualization about CSR in that the theories are grouped into instrumental, political, integrative and value based. Instrumental theory is focusing on achieving economic objectives through social activities; political focusing on a responsible use of business power in the political arena; integrative concentrating on drawing together management issues, public responsibility, stakeholder management and corporate social performance; and ethical theory is emphasizing strategies to achieve a good society (Babalola, 2012).

\subsection{Empirical review}

Generally, it is quite believed that corporate social responsibility (CSR) could increase company profits and thus most large companies are actively engaged in it. It is understood that CSR can promote respect for their company in the marketplace which can result in higher sales, enhance employee loyalty and attract better personnel to the firm. Also, CSR activities focusing on sustainability issues may lower costs and improve efficiencies as well. This may enhance the company's stock price, making executives' stock and stock options more profitable and shareholders happier (Robins, 2011). Using total assets or total revenue (as a proxy for firm size), some previous studies (e.g. Pattern 1992; Deegan\& Gordon,1996) that examined the association between 
the CSR disclosure and firm's size finds a significant and positive association. However, some studies denied such association or did not confirm that such association exists(see Aly, Simon \&Hussainey, 2010; Samaha\&Dahawy 2011; Reverte 2009; Elsayed\&Rozik 2011; Keelia\& Kuntz 1981).

Mcwilliams\& Siegel (2006)outlined a supply and demand model of corporate social responsibility (CSR). Based on this framework, it was hypothesized that a firm's level of CSR depended on its size, level of diversification, research and development, advertising, government sales, consumer in-come, labor market conditions, and stage in the industry life cycle. From these hypotheses, it was concluded that there was an "ideal" level of CSR, which managers could determine via cost-benefit analysis, and that there is a neutral relationship between CSR and financial performance.

Keffas\&Olulu-Briggs (2011) examined the financial performance of CSR and Non-CSR banks using financial ratios and frontier efficiency analysis. It was stated that accounting information got for banks in Japan,US and UK quoted on the FTSE4Good global index from Bank scope database. They included thirtyeight (38) financial and economic ratios based on variables such as Asset quality, Capital, Operations and Liquidity; that captured major scope of financial performance. In addition, they used a non-parametric linear programming technique known as Data Envelopment Analysis to create a piecewise linear frontier that helps to determine the efficiency levels for both a common and separate frontier analysis. First, it was found that there is positive relationship between corporate social responsibility and financial performance (FP). Banks that incorporate CSR have better asset quality; capital adequacy; and are more efficient in managing their asset portfolios and capital. Second, it was also found that geographic location regulates the relationship between CSR and FP during economic contraction, such that the relationship differs across relationship and transactional banking models.

Olayinka\&Temitope (2011) used qualitative research method to examine the relationship between corporate social responsibility and financial performance in Nigeria. The study obtained data on variables which were believed to have relationship with CSR and financial performance. These variables included Return on Earnings, Return on Asset, Community Performance, Employee Relation and Environment Management System. The result shows that CSR has a positive and significant relationship with the financial performance measures. These results reinforced the accumulating body of empirical support for the positive impact of CSR on financial performance.

Branco\& Rodrigues (2008) investigate to ascertain whether Portuguese banks use their websites as one of the media to disclose social responsibility information and also to identify what type of information they disclosed, and compare such disclosure with similar disclosure in annual report. Their findings suggest Portuguese banks seem to attribute greater importance to annual report as disclosure media than to websites. Banks with a higher visibility among consumers seems to exhibit greater concern to improve on image through high CSR disclosure in annual report and on websites.

A study carried out by Amole, Adebiyi\&Awolaja (2012) on the impact of corporate social responsibility on the profitability of Nigerian banks, which made use of ordinary least square (OLS) model of regression in testing the relationship between dependent and independent variables. The study used data on corporate social responsibility expenditure and profit after tax for the period of 2001-2010. It adopts model on the causal relationship between CSR and firms financial performance (FFP). The results of the regression analysis revealed that for every unit change increment in the CSR expenditure, there will be $95 \%$ increase in the profit after tax of the bank. The R-Square value of 0.893 obtained shows that CSR accounted for $89 \%$ of the variation in the profit after tax of the bank. The study finds that there is positive relationship between banks CSR activities and profitability, stating the need for banks to demonstrate high level of commitment to corporate social responsibility based on stakeholders theory in order to enhance their profitability in the long run.

Babalola(2012) examined the relationship between corporate social responsibility and firms' profitability in Nigeria with the use of secondary data, sourced from ten (10) randomly selected firms' annual report and financial summary between "1999-2008". The study makes use of ordinary least square for the analysis of collected data. Findings from the analysis show that the sample firms invested less than ten percent of their annual profit to social responsibility. The co-efficient of determination of the result obtained shows the depicts that the explanatory variable account for changes or variations in selected firms performance (PAT) are caused by changes in corporate social responsibility (CSR) in Nigeria while recommends that laws and regulations to obligate firms to be recognized, adequate attention should be given to social accounting in terms of social costs and to comply with social responsibility should be enacted.

Luper (2013) showed that there is need for the Nigerian banks to rethink Corporate Social Responsibility (CSR) in all the key sectors (such as education, power, health, agriculture, and small and medium-sized enterprises) of the economy. Empirically, using the data on commercial banks loans to SMEs provided by the CBN statistical bulletin for the period of ten years (from 2001-2010). The results of the descriptive statistics and sample t-test shows that, bank consolidation in Nigeria has led to a decline in SMEs financing to less than one percent on average in the study period, and there is no significant improvement in 
SMEs financing in Nigeria before and after bank consolidation. This clearly indicates that Nigerian Banks are not committed to their CSR (economic responsibilities) of financing to SMEs which is critical in mitigating these economic challenges and enhancing economic growth. The study recommends among others that, there should be further diversification in SMEs financing. In order to improve the CSR of Nigerian banks, there is also the need for banks to help in the training of SMEs owners as a matter of necessity on the need to maintain proper accounting records in the country.

Richard\&Okoye (2013) examined the effect of corporate social responsibility on the deposit money banks in Nigeria. The objective of this study is to determine the effect of corporate social responsibility on the performance of Nigerian deposit money banks. The study adopted descriptive survey design in carrying out the study. The empirical review of this study relied on the relationship between corporate social responsibility and performance of developed and developing countries deposit money banks like Nigeria. The study reveals that Social responsibility has a great impact on the society by adding to the infrastructures and development of the society. It is also concluded that a company has to give back to the society in which it operates, clean up all forms of pollution it has caused in its course of operation and also provide infrastructural facilities to the society as a way of giving back and developing the society.

Terungwa(2010) quest to know how socially responsible the banking system is responding to this vital developmental issue. Small and Medium Enterprises Equity Investment scheme (SMEEIs) is an umbrella under which banks came together to supposedly attend to this problem. The study made use of secondary data which was the ratio of loans to SMEs by commercial and merchant banks to their total credit for the period between 1993-2008.A paired sample t-test was used to test the significance of bank loans before and after the introduction of SMEEIS. It is found out that SMEEIs did not make any significance impact on loan disbursement to SMEs.

Bessong\&Tapang (2012) aimed at determining the influence of social responsibility cost on the profitability of Nigerian banks. The study made used of an exploratory research design and data were collected from five Nigerian banks through secondary sources and analyzed using the Ordinary Least Square (OLS) method. The study revealed that there is a negative influence between social cost and pollution cost on profitability. Conclusively, social responsibility cost is as vital as all other liabilities of the banks, and it requires proper management.

Akinpelu,Ogunbi ,Olaniran\&Ogunseye (2013) investigatesd the various types of social responsibility activities information that were disclosed by Nigerian commercial banks and the factors that determine the level of disclosure in their annual reports and accounts. Descriptive data analysis results indicated that commercial banks in Nigeria disclosed more information on human resources and community involvement and very low information on environmental, product quality and consumer relation. The outcome of multivariate analysis suggested that value of total assets have positive relationship and statistically significant with the level of corporate social responsibility activities disclosure, although, gross earnings and number of branches are positively and significantly related with Corporate Social Responsibility Disclosure (CSRD) level.

From the above, it can be concluded that most of these studies have looked at CSR expenditure on bank profitability in Nigeria, but they failed to look at the impact of information contents of CSR disclosed on bank profitability. This present study intends to fill this gap by looking at the effect of CSR activity disclosure on bank profitability in Nigeria.

\section{Methodology}

The multiple regression analysis using Ordinary Least square (OLS) was adapted to test whether corporate social responsibility disclosure has impacted on the corporate returns in Nigerian bank industry. Data were sourced from annual reports and accounts of twelve (12) selected banks in Nigeria for the year 2012 only. The study employs the scoring system of Branco\& Rodrigues (2006) to analyze social responsibility disclosure among the sampled banks in Nigeria. The scoring system is organized into four themes with each theme having subthemes: environmental (7), human resources (9), product quality and consumer relation (4), and community involvement (5), Makingtotal of twenty-five(25); with each subtheme assigned one, for the disclosure in annual report and accounts of each bank in the study (see appendix).

\subsection{Model specification}

The study employs econometric model to analyze the effect of corporate social responsibility activity disclosure on corporate profitability.It is expected that there would be positive relationship between corporate social responsibility disclosure score and bank profitability. Two control variables such as bank size and owners' equity have been incorporated in the model. Hence, the study also expects that the higher the expansion of bank's size, the higher the profitability of banks.However, the business of financial intermediation is exposed to various forms of risks such as interest rate risk and credit risk. In this manner, the profitability of a bank would be dependent on the management's attitude towards risk and can be analyzed by examining the capital 
and reserves (owners 'equity) a bank chooses to hold and its liquidity management policies. Therefore, the study expects that a bank with higher capital and reserves (CR) would be considered relatively safer in the event of loss or liquidation, hence, it is assumed to have low leverage or risk. The traditional risk-return proposition suggests a negative relationship between capital and bank profitability. However, from the words of Koehn \&Santomero(1980) who stated that regulation which increases the capital adequacy requirements would increase the capital to assets ratio and thus reduce the risk. This would induce banks to absorb greater risk in their asset portfolios in the hope of maximizing expected returns. Hence, this suggests another relationship that there is possibility to have a positive relationship between bank profitability and, capital\& reserves (Total equity).

The model is therefore specified as follows:

Roe $=\mathrm{f}(\mathrm{csr}$, asset, $\mathrm{cr})$

In specific form,

Roe $=\alpha_{0}+\beta_{1}$ csr $+\beta_{2} \log ($ asset $)+\beta_{2} \log (\mathrm{cr})+\mathrm{u}$.

Where:

$\alpha_{0}=$ intercept parameter(constant)

$\mathrm{Roe}=$ returns on equity as a proxy for corporate profitability,

csr=corporate social responsibility disclosure score

Asset=total assets as a proxy for corporate size

$\mathrm{Cr}=$ capital and reserves as a proxy for total equity

$\mathrm{U}=$ error term

3.2 Apriori expectation

$\beta_{1}, \beta_{2},>0$, and, $\beta_{3}<0$, CR \& ASSET serve as control variables.

\section{Discussion of results}

The estimated results of the model are presented in table $\mathbf{1}$ at the appendix. The parameters of corporate social responsibility scored disclosure (CSR) and that of total assets as a measure of bank size (ASSET) are positive which follows the apriori expectations meaning that both exhibit positive relationship with the profitability(ROE) of bank. While the parameter of Equity or Capital and reserves (CR) exhibits negative relationship with profitability of bank. It means that a unit increased in CSR will lead to $0.59 \%$ increases in Profitability on average; similarly, a percentage point increased in ASSET will make profitability(ROE) to increase by 0.38 on average. On the other hand, a percentage point increased in owner's Equity (CR) will lead to a fall in profitability by 0.28 on average.

Although, the parameter of CSR is not significant, those of ASSET and CR are significant at 5\% level of significance. The coefficient of determination $\left(\mathrm{R}^{2}\right)$ reflects that $83.4 \%$ variation in the profitability of bank is explained by the model. The value of F-calculated of 13.45815 is a clear indication that the model passes the test of overall significant at 5\% level of significance. In addition, Durbin-Watson test (D) statistic is 2.0966 which is compared with the tabulated values (Lower limit $\left(\mathrm{D}_{\mathrm{L}}\right)$ of 0.658 and Upper limit $\left(D_{U}\right)$ of 1.864) shows that no evidence of positive first-order serial correlation.

\section{Conclusion and recommendation}

From the above analysis, the results show that the bank's size has a positive and significant effect on profitability of banks. The higher the expansion of bank's size, the higher the profitability of banks. Also the results indicate that capital and reserves (equity) has a negative relationship with profitability of banks. This means that banks with higher capital and reserves (owners' equity) would be considered relatively safer in the event of loss or liquidation, hence, it is assumed to have low leverage or risk. It follows that the lower the capital and reserves (owners' equity) the higher the loss(or the lower the profit).Since the parameter of interest is that of CSR scored disclosure, the positive relationship between the ROE and the CSR offered a clear indication of the positive effect of corporate social responsibility disclosure(CSR) on the profit of banks. Since Return on Equity is a mean of measuring the profitability of owners' investment. It is used as a barometer for monitoring upswings and downswings in the financial performance of a firm. It follows that a continuous investment and an increase in corporate social responsibility disclosure by banking firms will positively increase the financial performance of banks in Nigeria as the result suggested.This view is supported by Babalola(2012), Amole, Adebiyi\&Awolaja (2012).

Based on conclusions from the empirical findings, it can be therefore recommended that since social responsibility cost and its disclosure can enhance profitability of banks hence, it requires proper management, every company should and needs to give back to the society in which it operates, clean up all forms of pollution it has caused in its course of operation and also provide infrastructural facilities to the society as a way of giving back and developing the society. There is need for banks to demonstrate high level of commitment to corporate social responsibility as suggested bystakeholders' theory in order to enhance their profitability in the long run. 
Finally, banks should improve and continue disclosing their social responsibility information in the annual report as disclosure media because banks with a higher visibility among consumers seem to exhibit greater concern to improve on good image through high Corporate social responsibility disclosure in annual report and on websites.

\section{References}

[1] Akinpelu,Y.A. ,Ogunbi ,O.J.,Olaniran,Y.A. \&Ogunseye, T.O. (2013). Corporate social responsibility activities disclosure by commercial banks In Nigeria. European Journal of Business and Management. 5(7),173-185.

[2] Amole, B. B., Adebiyi, S. O. \&Awolaja, A. M. (2012). Corporate social responsibility and profitability of Nigeria banks - A casual relationship. Research Journal of Finance and Accounting, 3(1),6-17.

[3] Aly, D., Simon, J. \&Hussainey, K. (2010). Determinants of corporate internet reporting evidence from Egypt. Managerial Auditing Journal, 25 ( 2), 182-202.

[4] Babalola, Y.A.(2012). The impact of corporate social responsibility on firms' profitability in Nigeria. European Journal of Economics, Finance and Administrative Sciences, 45(2012),41-50.

[5] Bessong, P.K. \&Tapang, A.T.(2012).Social responsibility cost and its influence on the profitability of Nigerian banks. International Journal of Financial Research,3(4),1-5.

[6] Branco, M. C. \& Rodrigues (2008). Factor influencing social responsibility disclosure by Portuguese companies. Journal of Business Research, 29( 1), 21-41.

[7] Carrol, A.B. (1979). A three-dimensional conceptual model of corporate performance .Academy of Management Review, 4(4), 497505 .

[8] Carroll, A. B.(1994). Social issues in management research. Business and Society, 33(1), 5-25.

[9] Deegan,C.D. \& Gordon, B.(1996). A study of the environmental disclosure practices of Australian corporations, Accounting and Business Research, 26(3), 187-199.

[10] Elsayed, M. \&Hoque, Z. (2010). Perceived international environmental factor and corporate

[11] voluntary disclosure practices an empirical study. The British Accounting Review, 42, 17-35.

[12] Friedman, M. (1970). The social responsibility of business is to increase its profits.New York Times Magazine, September 13: $32-$ $33,122,124,126$

[13] Garriga, E. \&Mele, D. (2004). Corporate social responsibility theories: Mapping and territory.Journal of Business Ethics, 53, 51-74.

[14] Gray, R., Owen, D. \&Adams.T. (1996.). Accounting and accountability Changes and challenges in corporate social and environmental Reporting. Prentice Hall Europe, Hemel Hempstead.

[15] Ikan, D. (2004). Reasons for social responsibility. International Journal of Investment and Finance,4 (1)

[16] Jamali,D. \&Mirshak,R. (2007). Corporate Social Responsibility (CSR):Theory and practice in a developing country context. Journal of Business Ethics (2007) 72,243-262. Springer 2006

[17] Kedia, B. L. \& Kuntz, E. C. (1981). The context of social performance. An empirical study of Texas banks research in corporate social performance and policy (3rd Edition). Greenwich: JAI Press.

[18] Keith, D. (2001). Social responsibility. Journal of Business and Common Market Studies, 7 (1)

[19] Keffas,G\&Olulu-Briggs,O.V.(2011). Corporatesocial responsibility: How does it affect the financial performance of banks? Empiricalevidence from us, uk and japan. Journal of Management and Corporate Governance,3, March 2011, 8-26.

[20] Koehn,M. \&Santomero,A.M.(1980). Regulation of bank capital and portfolio risk. Journal of Finance,35,1235-1250

[21] Lombardo, A. A. (2009). Corporate social responsibility and its impact on the profit of a company, Journal of Business and Social Science, $1(\mathrm{i})$

[22] Longe, B. C., Necker, Moore, Petty \&Palich (2006). Characteristics of corporate social responsibility. Journal of Social Sciences. 2(2)

[23] Luper, I. (2013). Rethinking banks corporate social responsibility (CSR) in Nigeria. International Journal of Finance and Accounting, 2(1), 30-36

[24] McOliver\&Yomere (2009). Introduction to business: The concept of social responsibility. Lagos: Malt House Press Ltd.

[25] Mcwilliams A. \& Siegel, D. S.(2006). Corporate social responsibility: International perspectives. Rensselaer Working Papers in Economics,available online at http://www.rpi.edu/dept/economics/www/workingpapers/ accessed on 23th October, 2013.

[26] McWilliams, A. \& Siegel, D. (2001). Corporate social responsibility: A theory of the firmperspective. Academy of Management Review, 26, 117-127.

[27] Obi, D. (2013). CSR: 8 banks spend N1.9bn to make social impact, This Business day News paper of July 9th, available at : www.businessdayonline.com. Accessed on October, $18^{\text {th }}, 2013$

[28] Olayinka, M. U. \&Temitope, O. F. (2011). Corporate social responsibility and financial

[29] performance in developing economies-The Nigerian experience. New Orleans, New Orleans International Academic Conference, 815-824.

[30] Pattern, D. M. (1992). Intra-industry environmental disclosures in response to the Alaskan oil spill: A noteon legitimacy theory. Accounting Organizations and Society. 17(5), 471-475.

[31] Parsons, T.(1961) An outline of the social system, in T. Parsons, E. A. Shils, K. D. Naegle and J. R. Pitts (eds.), Theories of Society. New York: Free Press.

[32] Preston, L. (Ed.). (1978). Research in corporate social performance and policy,Greenwich, CT: JAI Press.

[33] Quazi, A. \& O’Brien, D. (2000). An empirical test of a cross-national model of corporate social responsibility, Journal of Business Ethics, 25, 33-51.

[34] Rechard, E.O \&Okoye,V. (2013).Impact of corporate social responsibility on the deposit money banks in Nigeria.Global Business and Economics Research,2(3), Available online at wwww.journal.globejournal.org. accessed on 23th November,2013.

[35] Robins R. (May, 2011).Does corporate social responsibility increase profits?Business Ethics -The magazine of corporate social responsibility. Available online at www.business-ethcs.com. Accessed on 23th October,2013.

[36] Reverte, C. (2009). Determinants of corporate social responsibility disclosure ratings by Spanish listed firms. Journal of Business Ethics. 88,(2), 357-366.

[37] Samaha, K. \&Stalepton, P. (2008). Compliance with international accounting standards in a nationalcontext some empirical evidence from the Cairo and Alexandria Stock Exchanges. Afro-Asian Journal ofFinance and Accounting,1(1), 40-66.

[38] Secchi, D. (2007). Utilitarian, managerial and relational theories of corporate social responsibility. International Journal of Management Reviews, 9(4), 347-373. 
[39] Terungwa. A.(2010). Corporate social respnsibility in nigerian banking system: The development of small and medium scale enterprises. Available online at www. Wbiconpro.com/615-azende.pdf .accessed on $25^{\text {th }}$ Novermber,2013.

[40] Unugbro, A. O. (2004). Management: Theory and practice. Benin City: Mindex Publishing.

[41] Votaw, D.( 1972). Genius became rare: A comment on the doctrine of social responsibility Pt 1', California Management Review 15(2), 25-31.

[42] Woodward, D.G.P., Edwards, F.\&Birkin (1996). Organizational legitimacy and stakeholder information provision. British Journal of Management, 7,329-347.

[43] Wright, P., \& Ferris, S. 1997. Agency conflict and corporate strategy: The effect of divestment on corporate value. Strategic management Journal, 18, 77-83.

\section{Appendix}

\section{Table 1: Eview-Results \\ Dependent Variable: ROE \\ Method: Least Squares}

Sample: 112

Included observations: 12

\begin{tabular}{|c|c|c|c|c|}
\hline Variable & Coefficient & Std. Error & t-Statistic & Prob. \\
\hline $\mathrm{C}$ & -1.216046 & 0.646786 & -1.880138 & 0.0969 \\
\hline CSR & 0.005989 & 0.018015 & 0.332445 & 0.7481 \\
\hline LOG(ASSET) & 0.381965 & 0.119350 & 3.200366 & 0.0126 \\
\hline $\mathrm{LOG}(\mathrm{CR})$ & -0.280511 & 0.053336 & -5.259310 & 0.0008 \\
\hline $\mathrm{R}$-squared & 0.834623 & \multicolumn{2}{|c|}{ Mean dependent var } & 0.220006 \\
\hline Adjusted R-squared & 0.772607 & \multicolumn{2}{|c|}{ S.D. dependent var } & 0.264570 \\
\hline S.E. of regression & 0.126162 & \multicolumn{2}{|c|}{ Akaike info criterion } & -1.041295 \\
\hline Sum squared resid & 0.127335 & \multicolumn{2}{|c|}{ Schwarz criterion } & -0.879660 \\
\hline Log likelihood & 10.24777 & \multicolumn{2}{|c|}{ Hannan-Quinn criter. } & -1.101139 \\
\hline F-statistic & 13.45815 & \multicolumn{2}{|c|}{ Durbin-Watson stat } & 2.096620 \\
\hline Prob(F-statistic) & 0.001714 & & & \\
\hline
\end{tabular}

Source: Authors' estimate

Table 2: The corporate social responsibility disclosure scores

\begin{tabular}{|c|c|}
\hline Theme & Indices \\
\hline Environmental & $\begin{array}{ll}\text { 1. } & \text { Environmental policies of the bank } \\
\text { 2. } & \text { Environmental management system and audit } \\
\text { 3. } & \text { Environmental awards } \\
\text { 4. } & \text { Lending and investment policies } \\
\text { 5. } & \text { Conversion of natural resources and recycle } \\
\text { 6. } & \text { Disclosure concerning energy and efficiency } \\
\text { 7. } & \text { Sustainability }\end{array}$ \\
\hline Human resources & $\begin{array}{ll}\text { 8. } & \text { Employee numbers } \\
\text { 9. } & \text { Employment remuneration } \\
\text { 10. } & \text { Employee share ownership } \\
\text { 11. } & \text { Employee consultation } \\
\text { 12. } & \text { Employee training and education } \\
\text { 13. } & \text { Disable employee } \\
\text { 14. } & \text { Trade union activity information } \\
\text { 15. } & \text { Employee health and safety } \\
\text { 16. } & \text { Employee assistance benefit } \\
\end{array}$ \\
\hline $\begin{array}{l}\text { Product quality and consumer } \\
\text { relation }\end{array}$ & $\begin{array}{l}\text { 17. Third party attestation } \\
\text { 18. Customer feedback on product and services channels } \\
\text { 19. Customer satisfaction of the quality of the product } \\
\text { 20. Customer complaint channels }\end{array}$ \\
\hline Community involvement & $\begin{array}{ll}\text { 21. } & \text { Charitable activities and donation } \\
\text { 22. Support for education } \\
\text { 23. Support for art and culture } \\
\text { 24. Support for public health } \\
\text { 25. Support for sporting or recreation project }\end{array}$ \\
\hline
\end{tabular}

Source: Branco\& Rodrigues (2006) 
The effects of corporate social responsibility activity disclosure on corporate profitability: Empirical

\section{Table 3: CSR Scores}

\begin{tabular}{|c|c|c|c|c|c|}
\hline Banks & Environmental & Human & $\begin{array}{l}\text { Product quality \& } \\
\text { customer relation }\end{array}$ & $\begin{array}{l}\text { Community } \\
\text { Involvement }\end{array}$ & Total \\
\hline 1 & 3 & 6 & 2 & 4 & 15 \\
\hline 2 & 6 & 8 & 3 & 4 & 21 \\
\hline 3 & 4 & 8 & 4 & 3 & 19 \\
\hline 4 & 4 & 6 & 3 & 4 & 17 \\
\hline 5 & 5 & 8 & 1 & 4 & 18 \\
\hline 6 & 3 & 7 & 2 & 4 & 16 \\
\hline 7 & 6 & 8 & 3 & 4 & 21 \\
\hline 8 & 5 & 6 & 2 & 4 & 17 \\
\hline 9 & 5 & 6 & 3 & 3 & 17 \\
\hline 10 & 6 & 7 & 4 & 3 & 20 \\
\hline 11 & 6 & 8 & 4 & 3 & 21 \\
\hline 12 & 6 & 8 & 4 & 3 & 21 \\
\hline
\end{tabular}

Source: Authors' computation 